\title{
Halk Sağlığı Perspektifinden Osteoporoz ile İlgili Gazete Haberleri Ne Söylüyor?
}

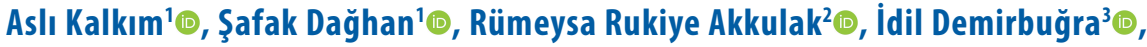 \\ Ayşe Münise Yavaş ${ }^{4}$ (I)
}

'Ege Üniversitesi Hemşirelik Fakültesi, Halk Sağlığı Hemşireliği Anabilim Dalı, İzmir, Türkiye

${ }^{2}$ Atatürk Eğitim Araştırma Hastanesi, Hemşire, Ankara, Türkiye

${ }^{3}$ Ege Üniversitesi Hastanesi, Genel Cerrahi Yoğun Bakım Kliniği, İzmir, Türkiye

${ }^{4}$ Şuan çalışmıyor, Hemşire

Aslı Kalkım, Öğr. Gör. Dr. Şafak Dağhan, Prof. Dr. Rümeysa Rukiye Akkulak, Hemşire İdil Demirbuğra, Hemşire Ayşe Münise Yavaş, Hemşire

Iletişim:

Öğr. Gör. Dr. Aslı Kalkım

Ege Üniversitesi Hemşirelik Fakültesi, Halk Sağlığı Hemşireliği Anabilim Dalı, İzmir, Türkiye Tel: +90 5064173673

E-Posta: aslikalkim@gmail.com

Gönderilme Tarihi : 30 Temmuz 2018

Revizyon Tarihi ： 07 Eylül 2018

Kabul Tarihi : 07 Eylül 2018
ÖZET

Amaç: Halk sağlığı perspektifinden osteoporoz ile ilgili gazete haberlerinin toplumu bilgilendirme açııından incelemektir.

Yöntem: Tanımlayıcı tipteki araştırmanın örneklemini, dokuz gazetede, 01 0cak 2010 ve 31 Aralık 2016 tarihleri arasında internette yayınlanan ve araştırma kriterlerine uyan, 163 gazete haberi oluşturmuştur. Gazete haberlerinin değerlendirilebilmesi için, iki bölümden ve 45 sorudan oluşan bir form kullanıımıştır. Veriler, SPSS 21.0 istatistiksel paket programı kullanılarak, sayı ve yüzde şeklinde değerlendirilmiştir.

Bulgular: 0steoporoz ile ilgili haberlerin \%26.4'ünün 2016 ylında yayınlandığı ve \%87.1'inde bilimsel kaynak bulunmadığı, \%84'ünde osteoporozun risk faktörlerinden bahsedildiği, \%59.5'inde hastalığın belirtilerinin yazııldı̆ı, \%85.9'unda osteoporozdan korunmaya yönelik önlemlere yer verildiği bulunmuştur. Korunmaya yönelik önlemler içerisinde; $\% 51.5^{\prime}$ inde kalsiyumdan zengin besinler, $\% 27.6^{\prime}$ 'snda egzersiz ve $\% 13.5^{\prime}$ inde güneşlenme / D vitamini ile ilgili bilgilerin yer aldığı görülmüş̧ür.

Sonuç: Gazetelerin topluma sağlıkla ilgili önemli bilgileri aktarmada, bireylerin tutum ve davranışlarını etkilemede önemli rolleri olduğu göz önüne alındığında, haber içeriklerinin bilimsel içeriklere dayalı olarak hazırlanması gerektiği, osteoporozla ilgili toplumda daha az bilinen noktaların ele alınması ve osteoporoza yönelik koruyucu önlemlerin daha fazla vurgulanması gerektiği düşünülmektedir.

Anahtar sözcükler: 0steoporoz, halk sağlığı, gazete.

\section{WHAT DO NEWSPAPERS SAY ABOUT OSTEOPOROSIS FROM THE PERSPECTIVE OF PUBLIC HEALTH? FROM A PUBLIC} HEALTH PERSPECTIVE?

\section{ABSTRACT}

Aim: The aim was to examine the newspaper coverage of osteoporosis from a public health perspective in terms of public awareness.

Methods: The sample of this descriptive study consisted of 163 news items from nine newspapers, published between 1 January 2010 and 31 December 2016, which accorded with the criteria of the study. In order to evaluate these news items, a form was used which consisted of two sections and 45 questions. Data were evaluated numerically and as percentages using the statistics package SPSS 21.0.

Results: It was found that $26.4 \%$ of the news items were published in $2016,87.1 \%$ did not give a scientific source, $84 \%$ discussed the risk factors for osteoporosis, $59.5 \%$ wrote about the symptoms of the disease, and $85.9 \%$ mentioned about the protection from osteoporosis and its prevention. Among the protective measures, $51.5 \%$ contained information on calcium-rich foods, $27.6 \%$ on exercise, and $13.5 \%$ on vitamin D and exposure to sunlight.

Conclusions: It is thought that as newspapers have an important role in passing on important information relating to public health and in affecting attitudes and behaviors, their news content should be prepared based on a scientific basis, they should deal with the aspects of osteoporosis which are less well-known to the public, and they should place greater emphasis on protective measures relating to osteoporosis.

Key words: 0steoporosis, public health, newspaper 
$\mathbf{0}$ steoporoz, toplumda ekonomik ve sosyal problemlere neden olan, önlenebilir ve tedavi edilebilir olması açısından halk sağlığını etkileyen önemli bir hastalıktır (1). Ülkemizde osteoporoz prevelansı erkeklerde \%7.5, kadınlarda \%12.9'dur (2). Literatürde yer alan çalışmalarda bireylerin osteoporoza yönelik bilgilerinin yetersiz olduğu (3-6), bilgisi olanların ise çoğunlukla bu bilgiyi gazete, televizyon, internet gibi medya aracılığıyla edindiği bildirilmiştir (7).

Sağlığı etkileyen etmenler, sağlığı geliştirmeye yönelik stratejiler ve eylemler çeşitlilik göstermektedir. Bu nedenle sağlığın geliştirilmesi konusu, sağlık ile işbirliğinde olan pek çok sektörü içine almaktadır (8). Bu sektörlerin en önemlilerinden biri olan medya, toplumun davranış kalıplarını, değer ve düşünce tarzlarını bireylere kazandırma ve öğrenilenlerin içselleştirilmesinde büyük öneme sahiptir (8-10). Medyanın bu etkisinin toplum sağlığını geliştirmede değerli bir yöntem olduğu kanıtlanmıştır (11).

Medya özellikle yazılı basın, değişik kültürel düzeydeki insanlara hitap edecek şekilde farklı içeriklerle düzenlenmekte ve geniş kitleleri etkileyebilme gücünü elinde bulundurmaktadır. Ayrıca, gazetelerin verdiği haberler, bireylerde uygun tutum ve davranışların gelişmesine de katkıda bulunmaktadır (12). Sağlık konusunda, gazetelerde birçok haber yer almakta ve bazı gazetelerde sağlıkla ile ilgili özel sayfalar bulunmaktadır. Gazetelerde çıkan sağlıkla ilgili bu yazılar, internet ortamında da yayınlandığı için geniş kitlelere ulaşabilmektedir (9). Bu açıdan bakıldığında, toplumun önceliklerinden olan sağlık için doğru kullanıldığında son derece yararlı bir araçtır. Aynı zamanda sağlık eğitiminin çok etkili bir tamamlayıCISı ve sağlık alanındaki eşitsizlikleri gidermede önemli bir faktördür (12).

Ülkemizde okuryazarlık oranı 15-19 yaş grubunda \%98, 45-49 yaş grubunda ise \%86'dır. Erkeklerin \%84'ü ilkokul veya üzerini tamamlamışken, bu oran kadınlarda \%72'dir. Erkek nüfusun ortanca tamamlanmış eğitim süresi 6.9 yıl, kadın nüfusda ise 4.7 yıldır (13).Tüm dünyada olduğu gibi ülkemizde de internet kullanım oranı giderek artmaktadır. Hanehalkı bilişim teknolojileri kullanım araştırması (2017) sonuçlarına göre, Türkiye genelinde internet erişim imkanına sahip hanelerin oranı 2017 yılında \%80.7'dir. İnternet kullanım oranı, 16-74 yaş grubundaki bireylerde \%66,8'dir. İnternet kullanım amaçları içerisinde $\% 65,9$ ile sağlıkla ilgili bilgi arama yer almaktadır (14).
Araştırmanın amacı halk sağlığı perspektifinden osteoporoz ile ilgili gazete haberlerini toplumu bilgilendirme açısından incelemektir.

Bu amaçla aşağıdaki sorulara yanıtlar aranmıştır:

1. Osteoporoz ile ilgili gazete haberlerinin genel özellikleri nelerdir?

2. Gazete haberlerinde yer alan osteoporoz risk faktörleri nelerdir?

3. Gazete haberlerinde yer alan osteoporoz belirtileri nelerdir?

4. Gazete haberlerinde yer alan osteoporozdan korunma önerileri nelerdir?

\section{Gereç ve Yöntem}

Araştırmanın tipi

Bu araştırma tanımlayıcı nitelikte bir araştırmadır.

\section{Araștırmanın evren ve örneklemi}

Araştırmanın evrenini, Türkiye'de internette yayınlanan gazetelerdeki osteoporoz ile ilgili haberler oluşturmaktadır. Araştırmanın örnekleminin belirlenmesi için bireylerin ücretsiz olarak internet üzerinden ulaşabildiği, ulusal yayın yapan gazetelerin içerisinden, tirajı en yüksek dokuz gazete incelenmiştir. Her bir gazetenin internet adreslerinden arşivlerine ulaşılarak "osteoporoz", "kemik erimesi" ve "kemik sağlığı" anahtar kelimeleri kullanılarak, 01 Ocak 2010 ve 31 Aralık 2016 tarihleri arasında yayınlanan 3696 habere ulaşılmıştır. Araştırmaya dahil edilme kriterleri olarak; haberin son altı yılda yayınlanmış olması, haber metninin bulunması, osteoporoz (kemik erimesi) ile ilgili olması gibi kriterler göz önünde bulundurulmuştur. Gazete haberinin 2010 yılı öncesinde yayınlanmış olması, haberde açıklayıcı metin bulunmaması ve sadece tanıtım, reklam gibi içeriğin bulunması araştırmada dışlanma kriterleri olarak belirlenmiştir. Araştırmanın örneklemine 163 gazete haberi dahil edilmiştir.

\section{Veri toplama araçları}

Gazete haberlerinin değerlendirilebilmesi için, araştırmacılar tarafından, literatür bilgileri doğrultusunda geliştirilen (15-18), iki bölümden ve 45 sorudan oluşan bir form kullanılmıştır. Bu formun ilk bölümünde; "gazete haberlerinin tanıtımı" ile ilgili olarak gazete ismi, haberin türü, yayınlandığı yıl, mevsim, gün, hazırlayan kişi, bilimsel dayanağı (bilimsel kaynak gösterimi), haberin kaynağı, reklam içerip içermediği ve reklam türü ilgili 10 soru yer almaktadır. İkinci bölümde osteoporoz ile ilgili gazete haberlerinin toplumu bilgilendirme açısından değerlendirmeye 
yönelik hazırlanan, toplam 35 sorudan oluşan "kontrol tablosu" ile haberin kelime sayısı, başlığının içerik ile uyumu, kullanılan kelimeler, haber metninin açık ve anlaşılırlığı, tıbbi terminoloji kullanımı, görsel kullanımı, görselin içeriği, haberin osteoporoza ilişkin konusu, osteoporozun önemine yer verme durumu, araştırma sonuçları, toplumda görülme sıklığı, kimlerde görüldüğü (4 soru), risk faktörleri ( 2 soru), belirtileri ( 2 soru), tanı yöntemleri ( 2 soru) ve korunma önerileri (14 soru) incelenmiştir. Kontrol tablosu kullanımı araştırmacılar arasında tutarlılığı sağlamada katkısı olmuştur.

Veri toplama formunun ön denemesi için 2010 yılı öncesi yayınlanan 15 gazete haberi, araştırmacılar tarafından bağımsız olarak incelenmiş, yapılan değerlendirmeler karşılaştırılmıştır. Farklılıklar doğrultusunda formda gerekli düzenlemeler yapılarak, formun son şekli oluşturulmuştur.

\section{Veri toplama yöntemi}

Gazete haberleri Ocak ve Şubat 2017 tarihleri arasında, araştırmacılar tarafından incelenmiş olup, her bir gazete haberi iki araştırmacı tarafından değerlendirilmiştir. Araştırma verilerinin iki farklı araştırmacı tarafından incelenerek karşılaştırılması ile iç geçerlik sağlanmıştır. Araştırmacıların bir gazete haberini okuma süresi haberin kapsamına göre değişiklik göstermekle birlikte, 12-15 dakika sürmüştür.

\section{Verilerin analizi}

Veriler, SPSS 21.0 istatistiksel paket programı kullanılarak, sayı ve yüzde şeklinde değerlendirilmiştir.

\section{Araştırmanın etiği}

Araştırma raporunda incelenen haberlerin yer aldığı gazetelerin isimlerine ve haberi yapan kişilerin isimlerine yer verilmemiştir.

\section{Bulgular}

\section{Osteoporoz ile Ilgili gazete haberlerinin genel özellikleri}

Osteoporoz ile ilgili haberlerin \%26.4'ü 2016 yılında (Grafik 1), \%34.4'ü sonbaharda ve \%77.9'u hafta içi yayınlanmıştır. Haberlerin \%79.1'i güncel durum ve bilgilendirme yazısıdır. Haber metinlerinin \%92'sinde haberi hazırlayan kişinin belirtilmediği, \%87.1'inde bilimsel dayanağı olmadığı, \%42.9'unda osteoporozu açıklayan bilgi kaynağının akademisyen ve \%32.5'inde doktor olduğu, \%14.1'inde reklam içeriği bulunduğu ve reklam bulunan metinlerin \%82.6'sında özel hastane reklamı bulunduğu belirlenmiştir (Tablo 1).
Tablo 1. Osteoporoz ile ilgili gazete haberlerinin genel özellikleri

\begin{tabular}{|c|c|c|}
\hline Gazeteler & $n$ & $\%$ \\
\hline $\begin{array}{l}\text { A } \\
B \\
C \\
D \\
\text { D } \\
F \\
G \\
H \\
\text { i } \\
\end{array}$ & $\begin{array}{c}24 \\
19 \\
18 \\
11 \\
8 \\
33 \\
24 \\
17 \\
9\end{array}$ & $\begin{array}{c}14.7 \\
11.7 \\
11.0 \\
6.7 \\
4.9 \\
20.2 \\
14.7 \\
10.4 \\
5.5\end{array}$ \\
\hline $\begin{array}{l}\text { Yayınlandığı mevsim } \\
\text { Sonbahar } \\
\text { KıŞ } \\
\text { Ilkbahar } \\
\text { Yaz } \\
\end{array}$ & $\begin{array}{l}56 \\
25 \\
38 \\
44\end{array}$ & $\begin{array}{l}34.4 \\
15.3 \\
23.3 \\
27.0\end{array}$ \\
\hline $\begin{array}{l}\text { Yayınlandığı gün } \\
\text { Hafta içi } \\
\text { Hafta sonu }\end{array}$ & $\begin{array}{c}127 \\
36\end{array}$ & $\begin{array}{l}77.9 \\
22.1\end{array}$ \\
\hline $\begin{array}{l}\text { Türü } \\
\text { Belirtilmemiş } \\
\text { Güncel durum ve bilgilendirme } \\
\text { Etkinlik }\end{array}$ & $\begin{array}{c}28 \\
129 \\
6\end{array}$ & $\begin{array}{c}17.2 \\
79.1 \\
3.7\end{array}$ \\
\hline $\begin{array}{l}\text { Haberi hazırlayan kişi } \\
\text { Belirtilmiş } \\
\text { Belirtilmemiş }\end{array}$ & $\begin{array}{c}13 \\
150\end{array}$ & $\begin{array}{c}8.0 \\
92.0\end{array}$ \\
\hline $\begin{array}{l}\text { Bilimsel dayanağı } \\
\text { Var } \\
\text { Yok } \\
\end{array}$ & $\begin{array}{c}21 \\
142\end{array}$ & $\begin{array}{l}12.9 \\
87.1\end{array}$ \\
\hline $\begin{array}{l}\text { Haberin kaynağı } \\
\text { Doktor } \\
\text { Diyetisyen } \\
\text { Akademisyen } \\
\text { Gıda mühendisi } \\
\text { Belirtilmemiş }\end{array}$ & $\begin{array}{c}53 \\
11 \\
70 \\
2 \\
27\end{array}$ & $\begin{array}{c}32.5 \\
6.7 \\
42.9 \\
1.2 \\
16.6\end{array}$ \\
\hline $\begin{array}{l}\text { Reklam içeriği } \\
\text { Evet } \\
\text { Hayır } \\
\end{array}$ & $\begin{array}{c}23 \\
140 \\
\end{array}$ & $\begin{array}{l}14.1 \\
85.9\end{array}$ \\
\hline $\begin{array}{l}\text { Reklam türü* }(\mathbf{n = 2 3 )} \\
\text { Gıda } \\
\text { Özel hastane } \\
\text { Toplam }\end{array}$ & $\begin{array}{c}4 \\
19 \\
163\end{array}$ & $\begin{array}{r}17.4 \\
82.6 \\
100.0\end{array}$ \\
\hline
\end{tabular}

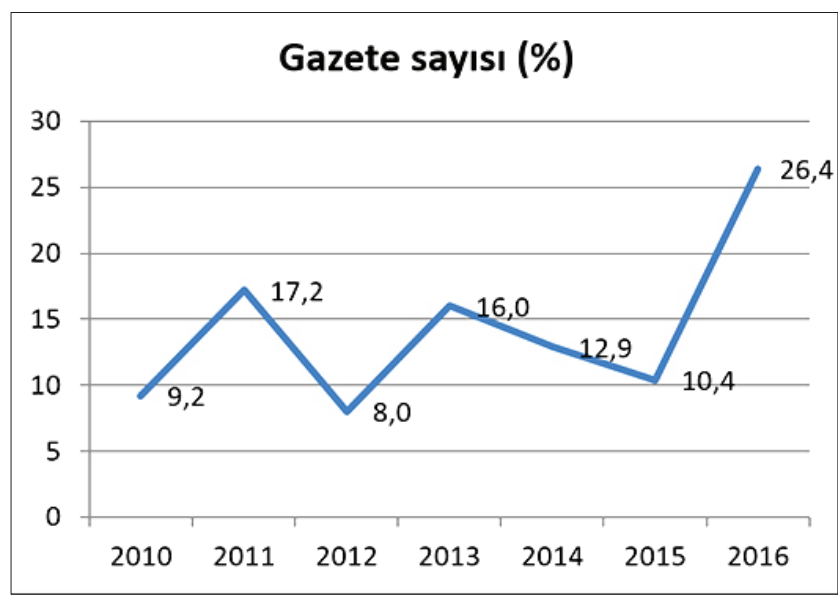

Grafik 1. Osteoporoz ile ilgili gazete haberlerinin yıllara göre dağılımı 
Osteoporoz ile ilgili gazete haberlerinin başlık ve metin özellikleri / içeriği

Haberlerin başlık ve metin özellikleri değerlendirildiğinde; \%93.9'unun başlığının içerik ile uyumlu olduğu, \%40.5'inde başıkta kemik erimesi kullanıldığı, ortalama kelime sayısının $X=378.68 \pm 199.93$ ( $\mathrm{min}=62$, $\mathrm{mak}=1152$ ) olduğu, \%96.3'ünün haber metninin açık ve anlaşılır olduğu, \%19.6'sında tıbbi terminoloji kullanıldığı, \%76.7'sinde görsel kullanıldığı, kullanılan görsellerin \%25.8'inin besin/ kalsiyumdan zengin besinler ile ilgili olduğu ve \%25.7'sinde kemik/vücut resmi olduğu belirlenmiştir (Tablo 2).

Tablo 2. Osteoporoz ile ilgili gazete haberlerinin başllk ve metninin özellikleri

\begin{tabular}{|c|c|c|}
\hline Başlık & $N$ & $\%$ \\
\hline \multicolumn{3}{|l|}{ İçerik ile uyumu } \\
\hline Uyumlu & 153 & 93.9 \\
\hline Uyumsuz & 10 & 6.1 \\
\hline \multicolumn{3}{|l|}{ Kullanılan kelime } \\
\hline Osteoporoz & 30 & 18.4 \\
\hline Kemik erimesi & 66 & 40.5 \\
\hline Kemik sağıı̆ı & 24 & 14.7 \\
\hline \multicolumn{3}{|l|}{ Haber metni } \\
\hline \multicolumn{3}{|c|}{ Ortalama kelime sayısı $X=378.68 \pm 199.93(\min =62, \operatorname{mak}=1152)$} \\
\hline \multicolumn{3}{|l|}{ Açık ve anlaşılır } \\
\hline Evet & 157 & 96.3 \\
\hline Hayır & 6 & 3.7 \\
\hline \multicolumn{3}{|l|}{ Tıbbi terminoloji kullanımı } \\
\hline Evet & 32 & 19.6 \\
\hline Hayır & 131 & 80.4 \\
\hline \multicolumn{3}{|l|}{ Görsel kullanımı } \\
\hline Var & 125 & 76.7 \\
\hline Yok & 38 & 23.3 \\
\hline \multicolumn{3}{|l|}{ Görsel* } \\
\hline Yaşlı birey & 28 & 22.6 \\
\hline Genç birey & 14 & 11.3 \\
\hline Sağlık çalışanı & 25 & 20.2 \\
\hline Spor & 10 & 8.1 \\
\hline Besin (Kalsiyumlu besinler) & 32 & 25.8 \\
\hline Vucut / Kemik & 32 & 25.7 \\
\hline Toplam & & \\
\hline
\end{tabular}

*Birden fazla seçenek işaretlenmiştir..

Gazete haberlerinin \%86.5'inde konunun önleme ve koruma ile ilişkili olduğu, \%66.3'ünde osteoporozun önemine, \%19.6'sında osteoporoz ile ilgili araştırma sonucuna ve \%27.6'sında osteoporozun toplumda görülme sıklığına yer verildiği görülmüştür (Tablo 3).
Tablo 3. Osteoporoz ile ilgili gazete haberlerinin metin içerikleri-

Konu*

Önleme / Koruma

Erken Tanı

Tedavi ve Rehabilitasyon

n

Osteoporozun önemi

Var

08

Yok

55

33.7

Osteoporoza ilişkin araştırma sonuçları

Var

32

19.6

Yok

131

80.4

Osteoporozun toplumda görülme sıklığı

Var

$45 \quad 27.6$

Yok

118

72.4

Osteoporozun risk faktörleri

Var

137

84.0

Yok

Risk faktörleri* $(n=137)$

Yaşlllık

52.6

Menopoz

51.8

Sigara

48.9

Yetersiz kalsiyum alımı

48.2

Cinsiyet

47.4

Alkol

44.5

Yeme bozukluğu

43.1

Sedanter yaşam

41.6

Genetik

39.4

Kortizon

Kahve/çay tüketimi

28.5

İlaç kullanımı

27.7

Zayiflık

25.5

Hormonal yetersizlik

24.1

D vit. eksikliği

24.1

Etnik köken

19.7

Fazla tuz, protein tüketimi

14.6

Kırık öyküsü

8.8

Aşırı kilo

5.8

Toplam

5.1

*Birden fazla seçenek işaretlenmiştir..

\section{Osteoporoz risk faktörleri}

Haberlerin \%84'ünde osteoporozun risk faktörlerinden bahsedildiği, risk faktörlerinden sıklıkla yaşılık (\%52.6), menopoz (\%51.8), sigara (\%48.9), yetersiz kalsiyum alımı (\%48.2), alkol kullanımı (\%44.5) ve sedanter yaşamın (\%41.6) yer aldığı saptanmıştır (Tablo 3). 
Tablo 4. Osteoporoz ile ilgili gazete haberlerinin metin içerikleri-II

\begin{tabular}{|c|c|c|}
\hline Osteoporozun kimlerde görüldüğü & $n$ & $\%$ \\
\hline Var & 119 & 73.0 \\
\hline Yok & 44 & 27.0 \\
\hline \multicolumn{3}{|l|}{ Kimlerde $(n=119)$} \\
\hline Kadınlarda & 28 & 23.5 \\
\hline Erkeklerde & 12 & 10.1 \\
\hline Kadın ve erkeklerde & 78 & 65.5 \\
\hline Çocuklarda & 1 & 0.9 \\
\hline \multicolumn{3}{|c|}{ Osteoporozun hangi yaş grubunda görüldüğü } \\
\hline Var & 109 & 66.9 \\
\hline Yok & 54 & 33.1 \\
\hline \multicolumn{3}{|l|}{ Yaş grubu* $(n=109)$} \\
\hline Yaşlllık & 58 & 53.2 \\
\hline Menopoz ve menopoz sonrası dönem & 101 & 92.7 \\
\hline Menopoz öncesi & 7 & 6.4 \\
\hline Ergenlik - Çocukluk & 23 & 21.1 \\
\hline \multicolumn{3}{|l|}{ Osteoporozun Belirtileri } \\
\hline Var & 97 & 59.5 \\
\hline Yok & 66 & 40.5 \\
\hline \multicolumn{3}{|l|}{ Belirtiler* $(n=97)$} \\
\hline Kırık & 95 & 97.9 \\
\hline Sırt-bel ağrısı & 46 & 47.4 \\
\hline Boy kısalması & 44 & 45.4 \\
\hline Kamburluk & 33 & 34.0 \\
\hline \multicolumn{3}{|l|}{ Osteoporoza Yönelik Korunma Önerileri } \\
\hline Var & 140 & 85.9 \\
\hline Yok & 23 & 14.1 \\
\hline \multicolumn{3}{|l|}{ Korunma Önerileri* $(n=140)$} \\
\hline Kalsiyumdan zengin beslenme & 108 & 77.1 \\
\hline Egzersiz & 93 & 66.4 \\
\hline Yeterli ve dengeli beslenme & 81 & 57.9 \\
\hline Güneşlenme (D vitamini) & 70 & 50.0 \\
\hline Sigara, alkol azaltılması & 53 & 37.9 \\
\hline Çay, kahve tüketiminin azaltılması & 35 & 25.0 \\
\hline Tuz tüketimini azaltma & 25 & 17.9 \\
\hline Düşmelerden korunma & 21 & 15.0 \\
\hline Kemik yoğunluğu ölçümü & 18 & 12.9 \\
\hline Toplam & 163 & 100.0 \\
\hline
\end{tabular}

*Birden fazla seçenek işaretlenmiş̧tir.

\section{Osteoporozun görülme durumu ve belirtileri}

Haberlerin \%73'ü osteoporozun çoğunlukla kimlerde görüldüğüne, \%65.5'i hem kadın hemde erkeklerde görüldüğüne değinmiştir. Haberlerin \%66.9'unda osteoporozun görülme zamanı ile ilgili bilginin olduğu, \%92.7'sinde görülme zamanının menopoz ve menopoz sonrası dönem olarak yazıldığı görülmüştür. İncelenen gazete haberlerinin \%59.5'inde hastalığın belirtilerinin yazıldığı, çoğunlukla kırık (\%97.9), sırt-bel ağrısı (\%47.4), boy kısalması (\%45.4), kamburluk (\%34) gibi osteoporoza yönelik belirtilerin paylaşıldığı bulunmuştur (Tablo 4).

\section{Osteoporozdan korunmaya yönelik önlemler}

Gazete haberlerinde osteoporozdan korunmaya yönelik önlemlere (\%85.9) rastlanırken, çoğunlukla bu önlemler içerisinde; kalsiyumdan zengin beslenme (\%77.1), egzersiz (\%66.4), yeterli ve dengeli beslenme (\%57.9) bulunduğu saptanmıştır (Tablo 4).

Haberlerin \%51.5'inde kalsiyumdan zengin besinler hakkında bilgi verildiği, bu besinlerin çoğunlukla süt ve süt ürünleri (\%97.6), yeşil sebzeler (\%63.1) olduğu, \%16.6'sında günlük tüketilmesi gereken kalsiyum miktarına ilişkin bilginin bulunduğu, bu bilginin \%85.2'sinde doğru olduğu, \%17.2'sinde günlük tüketilmesi gereken süt miktarı önerisinin bulunduğu, \%25'inde bu bilginin doğru olduğu belirlenmiştir. Haberlerin \%27.6'sında egzersiz ile ilgili bilginin yer aldığı, çoğunlukla yürüyüş (\%75.6), dans (\%26.7), ağırlık kaldırma (\%24.4) gibi egzersizlerin yazıldığı, $\% 68.2$ 'inde haftada 3 kez ve üstü egzersiz yapılması gerektiği bildirilmiştir. Güneşlenme / D vitamini ile ilgili bilgi, haberlerin $\% 13.5^{\prime}$ inde yer almış ve $\% 68.2^{\prime}$ sinde bu bilgi yanIış şekilde verilmiştir. Osteoporoz için önerilen önlemlerin hangi yaş grubunda başlanması gerektiği bilgisi haberlerin \%40.5'inde yer almıştır, çoğunlukla çocukluk (\%68.2), ergenlik (\%37.9) döneminde başlanması gerektiği yazılmıştır (Tablo 5). İncelenen haberlerin \%19'u osteoporoza yönelik tanı yöntemlerine yer vermiş, tanı yöntemi olarak \%93.5'i kemik mineral yoğunluğu ölçümünden (dual X-ray absorbsiyometri yöntemi), diğer gazete haberleri röntgen ve kan testinden bahsetmiştir.

\section{Tartışma}

Son yıllarda özellikle 2016 yılında osteoporoz ile ilgili gazete haberlerinin oldukça arttığı görülmüştür. Osteoporoza yönelik gazete haberlerindeki artan ilgi hem dünyadaki hem de ülkemizdeki yaşlı nüfusun artmasıyla ilişkilendirilebilir. Dünya nüfusunun 2016 yılında \%8,7'sini yaşlı nüfusu oluşturmakta iken, ülkemizde yaşlı nüfusun toplam nüfus içindeki oranı 2012 yılında \%7,5'den, 2016 yılında $\% 8,3$ 'e yükselmiştir (19). Ayrıca osteoporoz ile ilgili gazete haberlerine sonbaharda daha fazla yer verilmiştir. Bu durumun 20 Ekim tarihinin Dünya Osteoporoz Günü olması nedeniyle, toplumun osteoporoz ile ilgili farkındalığını artırmak amacıyla ilişkili olduğu düşünülmektedir.

Haber metinlerinin çoğunluğunda haberi hazırlayan kişinin belirtilmediği ve bilimsel dayanağının bulunmadığı dikkat çekmektedir. Haberlerde osteoporozu açıklamada yararlanılan bilgi kaynağının çoğunlukla akademisyen veya doktor olduğu görülmektedir. Bu faktörler okuyucuların yazılan habere güvenip, güvenmeyeceğini etkilemesi 
Tablo 5. Osteoporoz ile ilgili gazete haberlerinin osteoporozdan korunmaya yönelik önlemlerine ilişkin içerikleri

\begin{tabular}{|c|c|c|}
\hline Kalsiyumlu besinler bilgisi & $N$ & $\%$ \\
\hline Var & 84 & 51.5 \\
\hline Yok & 79 & 48.5 \\
\hline \multicolumn{3}{|l|}{ Kalsiyumlu besinler* $(n=84)$} \\
\hline Yeşil sebzeler & 53 & 63.1 \\
\hline Kuruyemiş & 33 & 39.3 \\
\hline Balık & 30 & 35.7 \\
\hline Yumurta & 14 & 16.7 \\
\hline Brokoli & 10 & 11.9 \\
\hline \multicolumn{3}{|l|}{ Günlük kalsiyum miktarı bilgisi } \\
\hline Yok & 136 & 83.4 \\
\hline \multicolumn{3}{|l|}{ Kalsiyum miktarı doğruluğu ( $n=27$ ) } \\
\hline Hayır & 4 & 14.8 \\
\hline \multicolumn{3}{|l|}{ Günlük süt miktarı önerisi } \\
\hline Var & 28 & 17.2 \\
\hline Yok & 135 & 82.8 \\
\hline \multicolumn{3}{|l|}{ Süt miktarı önerisi doğru $(\mathrm{n}=28)$} \\
\hline Evet & 7 & 25.0 \\
\hline Hayır & 21 & 75.0 \\
\hline \multicolumn{3}{|l|}{ Egzersiz bilgisi } \\
\hline Var & 45 & 27.6 \\
\hline Yok & 118 & 72.4 \\
\hline \multicolumn{3}{|l|}{ Egzersiz türleri* $(n=45)$} \\
\hline Yürüyüş & 34 & 75.6 \\
\hline Dans & 12 & 26.7 \\
\hline Ağırlık kaldırma & 11 & 24.4 \\
\hline Aerobik & 9 & 20.0 \\
\hline Koşma & 7 & 15.6 \\
\hline \multicolumn{3}{|l|}{ Egzersiz sıklığı bilgisi ( $n=22)$} \\
\hline 3 kez ve üstü / haftada & 15 & 68.2 \\
\hline 3 kezden az / haftada & 7 & 31.8 \\
\hline \multicolumn{3}{|l|}{ Güneşlenme / D vit. bilgisi } \\
\hline Var & 22 & 13.5 \\
\hline Yok & 141 & 86.5 \\
\hline \multicolumn{3}{|l|}{ D vit. miktarı $(n=22)$} \\
\hline Doğru & 7 & 31.8 \\
\hline Yanlış & 15 & 68.2 \\
\hline \multicolumn{3}{|l|}{ Koruyucu önlemler yaş grubu bilgisi } \\
\hline Var & 66 & 40.5 \\
\hline Yok & 97 & 59.5 \\
\hline \multicolumn{3}{|l|}{ Yaş grubu* $(n=66)$} \\
\hline Menopoz ve menopoz sonrası dönem & 13 & 19.7 \\
\hline Menopoz öncesi dönem & 10 & 15.2 \\
\hline Ergenlik & 25 & 37.9 \\
\hline Çocukluk & 45 & 68.2 \\
\hline Gebelik & 10 & 15.2 \\
\hline Yaşlılık & 5 & 7.6 \\
\hline Toplam & 163 & 100.0 \\
\hline
\end{tabular}

*Birden fazla seçenek işaretlenmiştir. adına önemlidir. Bireylere hastalıklar ile ilgili sunulan bilgilerde, basit ve yalın bir dilin kullanılması (20) ve tıbbi terminoloji yerine halk arasında daha iyi bilinen kelimelerin seçilmesi, toplum tarafından bu bilgilerin daha anlaşılır olmasını sağlayacaktır (21). Bu açıdan bakıldığında haberlerin çoğunluğu açık ve anlaşılır, çok azında tıbbi terminoloji kullanılmıştır. Haberlerin dörtte üçünde görsel mesajlar kullanılmıştır. Konu ile ilgili uygun görsel mesajların kullanımı ile okuyucunun konuya ilgisi çekilerek, bilgi aktarımı daha etkin şekilde olur. Gazetelerde osteoporoza ilişkin araştırma sonuçlarına ve toplumda görülme sıklığına ilişkin bilgiye çok az yer verildiği görülmüştür. Öte yandan hastalıkla ilgili toplumda farkındalık oluşturmada bu iki konunun aktarılması son derece önemlidir.

Osteoporoza yönelik risk faktörlerinin bilinmesi ve hastalığın erken tanılanması, ilerleyen dönemde osteoporoz nedeniyle ortaya çıkabilecek komplikasyonlarla baş etmekten daha kolay ve maliyet etkin bir yaklaşımdır. Bu nedenle topluma osteoporoza yönelik risk faktörleri konusunda bilgilerin iletilmesi önceliklidir. Ancak haberlerde aşırı kilolu olma, kırık öyküsü, fazla tuz ve protein tüketimi, kortizon kullanımı, çay/kahve tüketimi ve zayıflık gibi osteoporoz risk faktörlerine oldukça az yer verilmiştir. Araştırmalarda da bireyler tarafından bu risk faktörlerinin daha az bilindiği vurgulanmaktadır $(6,7,22)$. Bu nedenle toplumu bilgilendirme açısından sıklıkla bilinen risk faktörlerinin yanı sıra daha az bilinen, diğer risk faktörlerinin de ele alınması gereklidir. Osteoporoz hem kadınlarda hem de erkeklerde görülebilen bir hastalıktır. Üç kadından birinin ve beş erkekten birinin osteoporotik kırık açısından risk altında olduğu tahmin edilmektedir (23). Gazete haberlerinin yarısından fazlasında da osteoporozun hem kadınlarda hem erkeklerde görülebileceğinden bahsedilmiştir. Osteoporoz sessiz ilerleyen bir hastalıktır. En önemli belirtileri kemiklerde oluşabilecek kırıklar, bel-sırt ağrıları ve kamburluktur (24). Gazete haberlerinin tamamına yakınında en önemli komplikasyon olan kırıklardan bahsedilmiş, yarısına yakınında da sırt-bel ağrısı, kamburluk gibi belirtilere yer verildiği görülmüştür. Bu fiziksel sorunların yanısıra, osteoporoz bireylerin günlük yaşam aktivitelerinin kısıtlanmasına, toplumsal izolasyona, depresyon gibi psikososyal sorunlara da neden olmaktadır (7).

Osteoporoz geri dönüşü olan bir hastalık olmamasına rağmen, bireylerin sağlıklı yaşam biçimi davranışlarını geliştirmeleri ile önlenebilir bir hastalıktır (25). Osteoporoz ile ilgili gazete haberlerinin çoğunluğunun osteoporozun önlenmesi ve korunmasıyla ilgili olduğu görülmüş olup, hastalığa ilişkin korunma önlemlerinin içerisinde çoğunlukla kalsiyumdan zengin beslenme ve egzersiz 
yer almıştır. Ancak güneşlenmek / D vitamini almak, risk faktörlerinden olan sigara alkol, çay, kahve ve tuz tüketiminin azaltılması gibi koruyucu önlemlere yönelik toplumun farkındalığının arttırılması da önemlidir. Haberlerde yer alan kalsiyumdan zengin besinler çoğunlukla süt ve süt ürünleridir. Brokoli gibi yeşil sebzeler ya da balık gibi diğer kalsiyum kaynaklarından oldukça az bahsedilmiştir. Özellikle süt ürünlerine yönelik intoleransı olan bireylere bu bilginin aktarılması ve alternatif yiyeceklerin sunulması önceliklidir. Bu açıdan bakıldığında, haberlerde bu konuya yeterli şekilde vurgu yapılmadığı görülmektedir. Kalsiyumdan zengin besinlerin bilinmesi kadar ne kadar tüketilmesi gerektiği de önemli bir konudur. IOF (2017) tarafından, 19-50 yaş arası bir yetişkin için günlük 1000 mg, postmenopoz dönemde (51+ yaş) ise $1200 \mathrm{mg}$ kalsiyum alımı önerilmektedir (26). Ancak oldukça az haberde bu bilginin olduğu görülmüştür. Diğer bir önemli koruyucu önlem olan egzersize yönelik bilgi sadece dört gazete haberinden birinde görülmektedir. Kemik sağlığının sürdürülmesinde önemli bir role sahip olan egzersize yönelik olarak, IOF (2017) kişinin haftada üç veya dört kere 30 ya da 40 dakika süren yük bindirici ve direnç egzersizlerini yapmasını önermektedir (27). Gazete haberlerinde günlük yaşamda uygulanabilirliği yüksek bir egzersiz olan yürüyüşe sıklıkla rastlanmıştır ancak diğer yük bindirici ve direnç egzersizlerinin de haberlerde yer verilmesi gerektiği düşünülmektedir. Egzersizin türü önemli olduğu kadar süresine de dikkat çekmek, en az ne kadar yapılırsa faydalı olur diyerek toplumu bilgilendirmek gereklidir. Bu bilgiye sadece 15 haberde yer verilmiştir. Kalsiyum emilimi için $D$ vitamini önemli bir ihtiyaçtır ve 50 yaş üzeri erişkinlerde günlük 800-1000 IU D vitamini alımı önerilmektedir (26). Haberlerin çok azında bu bilgiye karşılaşımıştır. Osteoporoz ile ilgili bilginin topluma aktarılmasını

\section{Kaynaklar}

1. Altın E, Karadeniz B, Türkyön F, Baldan F, Akkaya N, Atalay NŞ, ve ark. Kadın ve erkek yetişkinlerde osteoporoz bilgi ve farkındalık düzeyinin karşılaştırılması. Turk J Osteoporos 2014;20:98-103. [CrossRef]

2. Meray J, Peker Ö, Tüzün Ş. Epidemiyoloji Türkiye çalışması Fracturk. Osteoporozda tanı ve tedavi. Türkiye Osteoporoz Derneği, 1. Baskı. ISBN: 978-605-63275-0-6, Galenos Yayınevi İstanbul, 2012;8-21.

3. Göksugüzel G. Kemik mineral yoğunluğu istenen bireylerin osteoporoz sağlık inancı bilgi düzeyi ve risk faktörlerinin belirlenmesi. Yayımlanmamış Yüksek Lisans Tezi. Atatürk Üni. Sağlık Bilimleri Ens. Halk Sağlığı Hemşireliği A.D., Erzurum, 2011.

4. Kalkım A, Dağhan Ş. Theory-based osteoporosis prevention education and counseling program for women: A randomized controlled trial. Asian Nurs. Res. 2017;11:119-27. [CrossRef]

5. Öztürk A. Ortopedi ve travmatoloji kliniklerinde yatan kadın hastaların osteoporoz bilgi düzeyi ve öz-etkililik algılarının değerlendirilmesi. İstanbul Üniversitesi Sağlık Bilimleri Enstitüsü Yayınlanmamış Yüksek Lisans Tezi, İstanbul, 2008. hedefleyen haberlerde, koruyucu önlemlere ilişkin bilgilerin aktarılması önemlidir. Kadınlarda doruk kemik kütlesi 30 yaşına kadar gelişmekte ve bu yaş sonrasında azalmaya başlamaktadır $(28,29)$. Bu nedenle ergenlik dönemi, osteoporozu önlemeye yönelik davranışların kazanılmasında en önemli zaman dilimidir (7). Gazete haberlerinin yarısından daha azında bu bilgi yer almakla birlikte, çocukluk ve ergenlik döneminde olması gerektiği istendik düzeyde olmasa da belirtilmiştir.

Incelenen haberlerin yaklaşık beşte birinde osteoporoza yönelik tanı yöntemlerinin yer aldığı görülmüştür. Erken tanı yöntemleri her hastalıkta olduğu gibi, sessiz ilerleyen osteoporozun belirlenmesi açısından da önemlidir ve gazete haberlerinde daha sık yer alarak toplumun bilgilendirilmesi için önemli bir girişimdir.

\section{SONUÇ}

Sonuç olarak, osteoporoza ilişkin gazete haberlerinin halk sağlığı perspektifinden incelendiği bu araştırmada; son yıllarda haber sayısında artış olduğu, haberlerde açık ve anlaşılır bir dil kullanıldığı, toplumun farkındalığını oluşturmada yetersiz olduğu, iki haberden birinde önemli risk faktörlerine yer verilmediği, hastalığın kırık dışındaki belirtilerine daha az yer verildiği ve korunma önlemlerine yönelik içeriklerinin yetersiz olduğu görülmüştür.

Gazetelerin topluma sağlıkla ilgili önemli bilgileri aktarmada, bireylerin tutum ve davranışlarını etkilemede önemli rolleri olduğu göz önüne alındığında, haber içeriklerinin bilimsel içeriklere dayalı olarak hazırlanması gerektiği, osteoporozla ilgili toplumda daha az bilinen noktaların ele alınması ve osteoporoza yönelik koruyucu önlemlerin daha fazla vurgulanması gerektiği düşünülmektedir.

6. Seçginli S. Kadınların osteoporoza ilişkin bilgi, inanç ve risk faktörlerinin incelenmesi. Atatürk Üniversitesi Hemşirelik Yüksekokulu Dergisi 2007;10:77-88.

7. Koç A, Aypak C, Yıkılkan H, Akbıyık Di, Görpelioğlu S. On sekiz-35 yaş arası kadınların osteoporoz hakkındaki bilgi tutum ve davranış düzeyleri. Turk J Osteoporos 2016;22:11-6. [CrossRef]

8. Özbaş S, Özkan S. Kadın sağlığını geliştirmede medyanın kullanımı ve etkisi. TAF Preventive Medicine Bulletin 2010:9:541-46.

9. Taşdemir A, Kuş Z. Yenilenen ilköğretim programı ile ilgili ulusal gazetelerde yayınlanan haberlerin içerik analizi. Educational Sciences: Theory \& Practice 2011;11:1-21.

10. Pirkis J, Francis $C$. Mental illness in the news and information media: A critical review. ISBN: 978-1-74241-754-7, Commonwealth of Australia, 2012

11. Durrant R, Wakefield M, McLeod K, et al. Tobacco in the news: An analysis of news paper coverage of tobacco issues in Australia. Tobacco Control 2001;12:ii75-81 
12. Yıldız I, Tanyıldızı Ni. Türkiye'de 2012 yılında sağlık haberlerinin ulusal yazılı basında yer alış biçimleri ve bilgilendirme düzeyleri (Habertürk, Hürriyet, Posta, Sabah, Sözcü Ve Zaman gazeteleri örneği). The Journal of Social Science 2015;2:122-41.

13. Türkiye Nüfus Sağlık Araştırması 2013 Hacettepe Üniversitesi Nüfus Etütleri Enstitüsü Ankara, Türkiye. http://www.hips.hacettepe.edu. tr/tnsa2013/rapor/TNSA_2013_ana_rapor.pdf. Erişim tarihi: 01 Mart 2019.

14. Türkiye İstatistik Kurumu (TÜIK). Hanehalkı Bilişim Teknolojileri Kullanım Araştırması, 2017. Heber Bülteni, 2017, Sayı: 24862, 18 Ağustos 2017. http://www.tuik.gov.tr/HbPrint.do?id=24862 Erişim tarihi: 01 Mart 2019.

15. Demircioğlu S, Bulanık E, Cennet Ö, Boybay Z, Benderlioğlu E, Aslan D. Ağustos, Ekim 2011 ve Şubat 2012 aylarında tirajı en yüksek ulusal beş gazetenin obezite konusundaki haberlerinin içerik açısından incelenmesi. TAF Prev Med Bull 2013;12:271-82.

16. Polat G, Yıldırım G, Polat HH. Tamamlayıcı alternatif tıp ile ilgili gazete haberlerinin gazetecilik, halk sağlığı ve tıbbi etik boyutuyla değerlendirilmesi. JHS 2014;11:814-35. [CrossRef]

17. Bell $L$, Seale $C$. The reporting of cervical cancer in the mass media: a study of UK newspapers. European Journal of Cancer Care 2011;20:389-94. [CrossRef]

18. Maclean A, Sweeting $H$, Walker L,Patterson C, Raisanen U, Hunt K. "It's not healthy and it's decidedly not masculine": A media analysis of UK newspaper representations of eating disorders in males. BMJ Open 2015;5:e007468. [CrossRef]

19. Türkiye İstatistik Kurumu (TÜiK). İstatistiklerle yaşlılar, 2016. Haber Bülteni, Sayı: 24644, 16 Mart 2017. http://www.tuik.gov.tr/ PreHaberBultenleri.do?id=24644 Erişim tarihi: 01 Mart 2019.

20. Balçık PY, Taşkaya S, Şahin B. Sağlık okur-yazarlığı. TAF Prev Med Bull 2014;13:321-26.
21. Selçuk EB, Tetik BK, Sönmez B, Tekindal MA. Postmenopozal dönemdeki kadınların osteoporoz hakkında bilgi, tutum ve davranışlarının değerlendirilmesi. Ankara Med J 2015;15:114-19. [CrossRef]

22. Aslan G, Kılıc D. Osteoporosis health belief, knowledge level and risk factors in individuals whose bone mineral density was required. BNJ 2017;3:162-73. [CrossRef]

23. International Osteoporosis Foundation (IOF). 2012. Osteoporosis. [Cited 10 September 2012]. Available from URL: http://www. iofbonehealth.org/

24. Akarırmak Ü. Osteoporozda klinik bulgular ve tanı. http://www. ailehekimligi.com.tr/userfiles/osteopain-medikal_dergi.pdf Erişim tarihi: 01 Mart 2019.

25. Vered I, Werner P, Shemy G, Stone O. Nurses' knowledge and perceptions about osteoporosis: A questionnaire survey. I.J.N.S. 2008;45:847-54. [CrossRef]

26. International Osteoporosis Foundation (IOF). 2017a. Calcium. [Cited 20 September 2017]. Available from URL: https://www. iofbonehealth.org/osteoporosis-musculoskeletal-disorders/ osteoporosis/prevention/calcium. Erişim tarihi: 01 Mart 2019

27. International Osteoporosis Foundation (IOF). 2017b. Exercise. [Cited 20 September 2017]. Available from URL:,https://www. iofbonehealth.org/exercise Erişim tarihi: 01 Mart 2019

28. Bartl R, Frisch B. Osteoporoz. Ed: Tan AA. İstanbul: Türkiye Klinikleri, Springer, 2006.

29. Shahbo GMAEM, El-Rahman MA, El-mowafy R. Evaluation of knowledge and self-efficacy about osteoporosis perception among females in the faculty of nursing in Port-Said, Egypt. I.J.C.S. 2016;9:72-79. 